\title{
Problematika Pembelajaran Matematika Materi Teorema Pythagoras Berdasarkan Kurikulum 2013
}

\author{
Rizcky Juliawan ${ }^{1}$, Azra Fauzi ${ }^{2}$, Lisda Ramdhani ${ }^{3}$, Syahrir $^{4}$ \\ ${ }^{123}$ STKIP Harapan Bima, Universitas Pendidikan Mandalika ${ }^{4}$ \\ Risky.juliawan@gmail.com, fauziazra1@gmail.com ${ }^{2}$, lisda_ramdhani@yahoo.com ${ }^{3}$, \\ syahrirmandala85@gmail.com ${ }^{4}$
}

\begin{abstract}
Abstrak. Penelitian ini membahas pembelajaran Matematika materi Teorema Pythagoras di SMP Negeri 2 Palibelo dalam kebijakan Kurikulum 2013. Tujuan dalam penelitian ini adalah untuk mendeskripsikan problem proses pembelajaran Matematika materi Teorema Pythagoras dengan kurikulum 2013. Penelitian ini menggunakan pendekatan kualitatif dengan jenis deskriptif. Subjek penelitian ini adalah guru matematika SMP Negeri 2 Palibelo. Teknik pengumpulan data yang digunakan adalah dengan metode observasi, wawancara dan dokumentasi. Observasi digunakan untuk melakukan pengamatan pada saat pembelajaran berlangsung, sehingga peneliti mendapatkan gambaran tentang implementasi pembelajaran matematika sesuai dengan kurikulum 2013. Dokumentasi digunakan untuk menganalisis pembelajaran dan rencana pelaksanaan pembelajaran. Wawancara digunakan untuk mengetahui keabsahan data yang peneliti dapatkan dari hasil observasi dan dokumentasi. Implementasi Kurikulum 2013 pada mata pelajaran matematika materi teorema pythagoras dalam pelaksanaannya belum maksimal. Guru sudah menerapkan pendekatan saintifik. Penilaian yang dilaksanakan pada mata pelajaran Matematika mengarah pada penilaian hasil belajar yang menilai pengetahuan, keterampilan dan sikap tetapi belum optimal. Kendala implementasi Kurikulum 2013 pada mata pelajaran matematika materi teorema pythagoras yaitu aspek menanya sulit dilaksanakan karena siswa tidak tahu apa yang ingin ditanyakan dan adanya sikap tidak percaya diri siswa.
\end{abstract}

Kata kunci: Pembelajaran Matematika, Teorema Pythagoras, Kurikulum 2013

\begin{abstract}
This study discusses the learning of Mathematics in Pythagorean Theorem material at SMP Negeri 2 Palibelo in 2013 Curriculum policy. The purpose of this study is to describe the problem of the process of learning Mathematics in Pythagorean Theorem material with the 2013 curriculum. This study uses a qualitative approach with descriptive type. The subject of this research is the mathematics teacher at Palibelo Public Middle School 2. Data collection techniques used are the method of observation, interviews and documentation. Observation is used to make observations while learning takes place, so researchers get a picture of the implementation of mathematics learning in accordance with the 2013 curriculum. Documentation is used to analyze learning and learning implementation plans. Interviews are used to determine the validity of the data that researchers get from observations and documentation. The implementation of the 2013 curriculum in mathematics subject to the Pythagorean theorem in its implementation has not been maximized. The teacher has applied a scientific approach. Assessments carried out in Mathematics subjects lead to an assessment of learning outcomes that assess knowledge, skills and attitudes but are not optimal. Obstacles to the implementation of the 2013 curriculum in mathematics subject to the Pythagorean theorem, namely the questioning aspect is difficult to implement because students do not know what they want to ask and there is a lack of confidence in students.
\end{abstract}

Keywords: Mathematics Learning, Pythagorean Theorem, Curriculum 2013 


\section{PENDAHULUAN}

Peningkatan mutu pendidikan merupakan suatu langkah yang dilakukan secara terencana, baik dilakukan dengan perencanaan jangka pendek, jangka menengah, maupun dilakukan dengan perencanaan jangka panjang. Perencanaan yang dilakukan untuk mengetahui sejauh mana pencapaian mutu pendidikan yang telah dilaksanakan baik dari segi proses pembelajaran dan hasil hasil belajar (Mulyasa, 2004; Aprianingsih, 2013). Pemerintah telah melakukan berbagai upaya untuk meningkatkan mutu pendidikan seperti pengembangan dan penyempurnaan kurikulum, pengembangan materi pelajaran, perbaikan sistem evaluasi, pengadaan buku dan alat pelajaran, perbaikan sarana pendidikan, peningkatan kompetensi guru serta peningkatan mutu kepala sekolah (Abrory \& Kartowagiran, 2014; Kusnadi, Tahmir, \& Minggi, 2014).

Kurikulum merupakan pedoman dalam proses pembelajaran yang sangat berperan penting untuk mencapai tujuan pembelajaran sehingga sebuah pembelajaran harus mempunyai pedoman untuk dijadikan panduan dalam proses pembelajaran, pedoman kurikulum merupakan cakupan yang luas dan harus dijelaskan terperinci oleh guru sesuai dengan standar, kriteria kurikulum tersebut (Porter, Polikof, \& Smithson, 2009). Kurikulum 2013 merupakan penyempurnaan dari kurikulum sebelumnya yaitu Kurikulum Tingkat Satuan Pendidikan (KTSP) dan dilaksanakan secara terbatas dan bertahap mulai tahun pelajaran 2013/2014 (Mulyasa, 2004; Aprianingsih, 2013). Kurikulum 2013 diharapkan bisa membawa perubahan agar manusia Indonesia memiliki kemampuan hidup sebagai pribadi dan warga negara yang beriman, produktif, kreatif, inovatif dan afektif serta mampu berkontribusi pada kehidupan bermasyarakat, berbangsa, bernegara dan peradaban dunia (Nurmalasari et al., 2013; Kuncara, Sujadi, \& Riyadi, 2016).

Kurikulum 2013 dilandasi pemikiran tantangan masa depan yaitu tantangan abad ke-21 yang ditandai dengan abad ilmu pengetahuan, knowledge-based society dan kompetensi masa depan. Kurikulum 2013 lebih ditekankan pada pendidikan berkarakter, terutama pada tingkat dasar yang menjadi pondasi bagi tingkat selanjutnya. Kurikulum 2013 bertujuan untuk mempersiapkan manusia Indonesia agar memiliki kemampuan hidup sebagai pribadi dan warga negara yang beriman, produktif, kreatif, inovatif, dan afektif serta mampu berkontribusi pada kehidupan bermasyarakat, berbangsa, bernegara dan peradaban dunia (Kuncara, Sujadi, \& Riyadi, 2016; Kusnadi, Tahmir, \& Minggi, 2014; Kusnadi et al., 2014). Menurut Draft Salinan Lampiran Peraturan Menteri Pendidikan dan Kebudayaan Republik Indonesia Nomor 103 Tahun 2014 tentang Pembelajaran pada Pendidikan Dasar dan Pendidikan Menengah, pembelajaran yang dilaksanakan pada Kurikulum 2013 menggunakan pendekatan saintifik atau pendekatan berbasis proses keilmuan (Aprianingsih, 2013). Pendekatan saintifik tersebut meliputi lima langkah pokok: Mengamati, Menanya, Mengumpulkan informasi (explorasi), Mengasosiasi (menggunakan pengetahuan) dan Mengkomunikasikan (Ahmad, 2014).

Implementasi Kurikulum 2013 dalam proses pembelajaran matematika merupakan pelaksanaan program kurikulum ke dalam praktik pembelajaran matematika, sehingga terjadi perubahan dalam diri peserta didik baik perubahan pengetahuan, keterampilan maupun sikap. Implementasi Kurikulum 2013 dalam proses pembelajaran terdiri dari tiga tahap yaitu tahap perencanaan, tahap pelaksanaan dan tahap penilaian. Dalam pelaksanakan Kurikulum 2013 guru harus dapat memahami konsep dasar kurikulum dan kemampuan merencanakan Kurikulum 2013 yaitu penyusunan Rencana Pelaksanaan Pembelajaran (RPP), pelaksanakan pembelajaran berbasis Kurikulum 2013 serta mampu melaksanakan penilaian (Kusnadi et al., 2014).

Perubahan kurikulum harus dipahami dan dilaksanakan oleh banyak pihak, karena kurikulum sebagai rancangan pembelajaran memiliki kedudukan yang sangat penting dalam semua kegiatan pembelajaran (Abrory \& Kartowagiran, 2014). Kurikulum juga 
menentukan kualitas pendidikan. Di sisi lain, membutuhkan sarana dan prasarana dalam pembelajaran, bahwa untuk meningkatkan hasil peserta didik tidak hanya mengubah praktek pembelajaran, tetapi juga membutuhkan sarana dan prasarana seperti buku peserta didik. Perubahan ini juga akan membawa dampak terhadap mata pelajaran yang diajarkan salah satunya adalah matematika (Jitendra, 2010)

Strategi implementasi kurikulum yang efektif dan efisien dalam pembelajaran matematika sangat dibutuhkan untuk mencapai tujuan pembelajaran karena dalam pembelajaran yang sesuai dengan kurikulum 2013 ada tiga tahapan yaitu pendahuluan, inti dan penutup. Pada dasarnya yang mendasari kegiatan pembelajaran pada Kurikulum 2013 adalah pendekatan ilmiah. Pendekatan ilmiah dianggap mampu meningkatkan keaktifan dan kreativitas peserta didik (Sholikin, 2015). Selain proses pembelajaran, penilaian hasil belajar merupakan salah satu hal yang penting, dimana akhir dari pembelajaran merupakan penilaian untuk mengetahui kemampuan peserta didik. Penilaian hasil merupakan proses pengumpulan informasi tentang pencapaian pembelajaran dalam kompetensi sikap spriritual dan sikap sosial, pengetahuan serta keterampilan yang dilakukan secara terencana dan sistematis, selama dan setelah proses pembelajaran (Sholikin, 2015).

Penelitian ini membahas tentang proses pembelajaran matematika materi teorema pythagoras di SMP Negeri 2 Palibelo dalam kebijakan Kurikulum 20013. Tujuan dalam penelitian ini adalah untuk mendeskripsikan problem proses pembelajaran matematika materi teorema pythagoras berdasarkan kebijakan kurikulum 2013.

\section{METODE PENELITIAN}

Penelitian ini menggunakan pendekatan kualitatif dengan jenis deskriptif. Subjek penelitian ini adalah guru matematika SMP Negeri 2 Palibelo. Teknik pengumpulan data yang digunakan adalah dengan metode observasi, wawancara dan dokumentasi. Observasi digunakan untuk melakukan pengamatan pada saat pembelajaran berlangsung sehingga peneliti mendapatkan gambaran tentang implementasi pembelajaran matematika materi teorema Pythagoras sesuai dengan kurikulum 2013. Dokumentasi digunakan untuk menganalisis pembelajaran dan rencana pelaksanaan pembelajaran. Wawancara digunakan untuk mengetahui keabsahan data yang peneliti dapatkan dari hasil observasi dan dokumentasi.

\section{HASIL}

Kaitannya dengan pedagogi, pembelajaran matematika adalah sebuah proses interaksi dan pengembangan antara guru dan siswa. Kurikulum 2013 memerlukan guru untuk menggunakan pendekatan saintifik dalam proses pembelajaran dimana langkahlangkah pendekatan saintifik meliputi: mengamati, menanya, mengumpulkan informasi/ mencoba, mengasosiasikan/ menalar dan mengkomunikasikan.

Hasil wawancara dengan guru diperoleh bahwa guru membuat RPP dengan mengacu pada contoh-contoh yang sebelumnya dan dikembangkan guru tersebut. Menurut guru, kegiatan pendahuluan meliputi presensi, memberikan motivasi, menyampaikan tujuan dan membahas PR. Kegiatan inti, mengamati dan menanya kemudian mendiskusikan selanjutnya presentasi. Kegiatan penutup, guru hanya menegaskan kegiatan pembelajaran, memberikan PR dan soal-soal serta kadangkadang menyuruh siswa mempelajari materi. Penerapan pendekatan saintifik sudah dilakukan walaupun terkendala oleh waktu, karena waktu yang digunakan lama sedangkan materi yang harus disampaikan cukup banyak.

Berdasarkan hasil observasi diperoleh bahwa guru memulai pembelajaran dengan memberikan salam dan siswa disuruh berdoa yang dipimpin oleh ketua kelas. Kemudian, dilanjutkan dengan menanyakan tugas sebelumnya. Guru kadang tidak menyampaikan kompetensi yang akan dicapai siswa dan kadang tidak memberikan motivasi. Pada kegiatan inti, guru melaksanakan pendekatan saintifik. Pada kegiatan penutup, guru memberikan tugas untuk dikerjakan di rumah dan memberikan salam. Guru kadang 
tidak merefleksikan kembali kegiatan pembelajaran.

Berdasarkan RPP guru, langkahlangkah pembelajaran dilakukan dengan pendekatan saintifik yang meliputi: mengamati, menanya, mengumpulkan informasi, mengasosiasikan dan mengkomunikasikan, baik dalam model pembelajaran maupun pada diskusi klasikal.

Berdasarkan hasil wawancara, guru melaksanakan penilaian sikap berupa observasi atau pengamatan dan penilaian pengetahuan berupa tugas. Kendala yang dihadapi yaitu pada aspek menanya, siswa harus dipancing agar siswa mau bertanya. Selanjutnya, Berdasarkan RPP guru, daftar nilai yang ada mencakup penilaian pengetahuan, keterampilan dan sikap. Penilaian pengetahuan untuk mata pelajaran matematika, guru melaksanakan tes tertulis dan penugasan. Penilaian keterampilan dilakukan dengan proyek. Penilaian sikap dengan observasi, penilaian diri dan penilaian antar siswa.

\section{PEMBAHASAN}

Hasil penelitian menunjukkan bahwa penyesuaian pada pedagogi dan belajar siswa, guru sudah melaksanakan kegiatan pembelajaran meliputi kegiatan pendahuluan, inti dan penutup. Pada kegiatan pendahuluan, guru kadang tidak menyampaikan kompetensi yang akan dicapai siswa dan kadang tidak memberikan motivasi. Pada kegiatan inti, guru sudah menerapkan pendekatan saintifik. Pada kegiatan penutup, guru kadang tidak merefleksikan kegiatan pembelajaran dan tidak merangkum materi. Penerapan pendekatan saintifik sudah dilakukan walaupun terkendala oleh waktu, karena waktu yang digunakan lama sedangkan materi yang harus disampaikan cukup banyak. Pada aspek menanya, siswa kadang bingung yang akan ditanyakan dan tak jarang pula siswa kurang percaya diri. Penilaian yang dilaksanakan sudah menerapkan penilaian yang mengarahkan pada penilaian pengetahuan, keterampilan dan sikap yang dirasa terlalu banyak namun guru tetap mengusahakan semaksimal mungkin agar implementasi Kurikulum 2013 dapat berjalan dengan baik.
Penelitian lainnya juga mengungkapkan bahwa perubahan besar yang terjadi pada Kurikulum Tingkat Satuan Pedidikan (KTSP) menjadi Kurikulum 2013 menyebabkan adanya beberapa guru yang belum sepenuhnya memahami maksud dari pada Kurikulum 2013 dan cara mengimplementasikannya. Akibatnya, pengembangan RPP, pelaksanaan dan evaluasi pembelajaran tidak berjalan secara optimal. Sehingga berdampak pada implementasi Kurikulum 2013 yang tidak sesuai harapan (Nurmalasari et al., 2013; Ahmad, 2014). Masalah kurikulum 2013 lainnya seperti multi tafsir juga menjadi hambatan dalam implementasi kurikulum 2013. Sebagai contoh, kurikulum 2013 menggunakan pendekatan saintifik dalam aktivitas pembalajaran dengan lima langkah pokok: Mengamati, Menanya, Mengumpulkan informasi (explorasi), Mengasosiasi (menggunakan pengetahuan) dan Mengkomunikasikan (Ahmad, 2014).

\section{SIMPULAN}

Implementasi Kurikulum 2013 pada mata pelajaran matematika khususnya materi teorema Pythagoras dalam pelaksanaannya belum maksimal. Guru sudah menerapkan pendekatan saintifik. Penilaian yang dilaksanakan pada mata pelajaran Matematika mengarah pada penilaian hasil belajar yang menilai pengetahuan, keterampilan dan sikap tetapi belum optimal. Kendala implementasi Kurikulum 2013 pada mata pelajaran matematika materi teorema pythagoras yaitu aspek menanya sulit dilaksanakan karena siswa tidak tahu apa yang ingin ditanyakan dan adanya sikap tidak percaya diri.

SARAN

Diharapkan kepada peserta didik agar menumbuhkembangkan sikap percaya diri sehingga proses KBM bisa berjalan lancar, kepada guru agar belajar dan terus mengembangkan cara mengajarnya agar kurikulum 2013 dapat berlangsung sesuai yang diharpakan menurut undang-undang yang berlaku dan bagi peneliti selanjutnya agar dapat lebih menggali dan mengembangkan persoalan kurikulum 2013 ini dalam penelitannya. 


\section{DAFTAR PUSTAKA}

Abrory, M., \& Kartowagiran, B. (2014). Evaluasi Implementasi Kurikulum 2013 pada Pembelajaran Matematika SMP Negeri Kelas VII di Kabupaten Sleman. Jurnal Evaluasi Pendidikan, 2(1), 50-59.

Ahmad, S. (2014). Problematika Kurikulum 2013 dan Kepemimpinan Instruksional Kepala Sekolah, 8(2012), 98-108.

Aprianingsih, N. (2013). Implementasi kurikulum 2013 pada mata pelajaran matematika di sekolah menengah pertama, 31-36.

Jitendra, A. K. (2010). An Evaluation of the Intended and Implemented Curricula's Adherence to the NCTM Standards on the Mathematics Achievement of Third Grade Students: A Case Study. Journal of Curriculum and Instruction(JoCI), 4(2), 35-50.

Kuncara, A. W., Sujadi, I., \& Riyadi. (2016). Analisis Proses Pembelajaran Matematika Berdasarkan Kurikulum 2013 pada Materi Pokok Peluang Kelas X SMA Negeri 1 Surakarta, 4(3), 352365.

Kusnadi, D., Tahmir, S., \& Minggi, I. (2014). Implementasi kurikulum 2013 dalam pembelajaran matematika di sma negeri 1 makassar, 2, 123-135.

Mulyasa, E. (2004). Manajemen Berbasis Sekolah. Bandung: PT Remaja Rosdakarya.

Nurmalasari, R., Dian, R., Wati, P., Puspitasari, P., Diana, W., \& Dewi, N. K. (2013). Peran Guru dalam Implementasi Kurikulum 2013, 722-733.

Porter, A. ., Polikof, M. ., \& Smithson. (2009). Is there a de facto national intended curriculum? evidence from state content standars. Educational Evaluation and Policy Analysis, 31, 238-268.

Sholikin, M. (2015). Implementasi Kurikulum 2013 Pembelajaran Matematika di SMP Muhammadiyah 1 Surakarta Kelas VII Tahun Ajaran 2014/2015. 